\title{
An Analysis of the Reasons Why Confucianism Became an Orthodox Thought in the Han Dynasty
}

\author{
Sen $\mathrm{Qi}^{1, *, \dagger}$, Xinyi Wang ${ }^{2, \dagger}$ \\ ${ }^{1}$ The International Department of Hanlin Experimental School, Dongguan, China \\ ${ }^{2}$ Beijing No. 8 Middle School, Beijing, China \\ ${ }^{*}$ Corresponding author. Email: qsdd920@gmail.com \\ ${ }^{\dagger}$ Those authors contributed equally.
}

\begin{abstract}
The Confucianism was struck seriously by the event of "burning books and burying Confucian scholars" during the period of Qinshihuang. However, at the beginning of Han Dynasty, from Gaozu to Wen-Jing, Huang-Lao which recommended discarding all desires and worries and having rest with the people was prevailing. This gave a chance for the Confucianism to be revived. A considerable number of Confucian scholars who advocated Confucianism also absorbed the ideas of legalism, Taoism and yin-yang school in order to better adapt to the rulers. Consequently, the changing of mainstream ideology to "Ban from hundred philosophers, venerate Confucianism" realized during the period of Emperor Wu. On the one hand, this paper combs the changes of mainstream thought in the early Han Dynasty; on the other hand, it focuses on the development of Confucianism in the period of Emperor Wen of the Han Dynasty. This paper discusses how Emperor Wen gradually paid attention to and made use of Confucianism from five aspects. This paper holds that it is a historical necessity for Confucianism to reach its peak in the period of Emperor Wu of the Han Dynasty, which laid an important foundation for the acceptance and development of Confucianism in the period of Emperor Wen of the Han Dynasty. This paper will be helpful to guide scholars to further discuss the development of Confucianism in the period of Emperor Wen of the Han Dynasty.
\end{abstract}

Keywords: Han Dynasty, Confucianism, ideological reform, Emperor wen

\section{INTRODUCTION}

Each dynasty needs an official guiding ideology, and deciding which ideology to use as the guiding ideology is not a difficult problem for the dynasties after the Han Dynasty. Because they basically chose to accept the system of the Han Dynasty and respect Confucianism. However, in the early Han Dynasty, this is a topic that needs to be debated. Although the Han Dynasty inherited the centralized system of the Qin Dynasty, great changes have taken place in the thought of state rule. The dominant thought of the Qin Dynasty was legalist thought, and the strict legalist thought led to the shortterm demise of the Qin Dynasty. The Han Dynasty fully absorbed the lessons of the previous dynasty and began to seek new ruling ideas.

In the early Han Dynasty, the dominant political ideology was primitive Taoism, known as Huanglao's school. The officials in the early Han dynasty did not all agree with Confucianism. They believed that
Confucianism was not the way to govern the world at the beginning of the dynasty because it involved a wide range of topics and few needs. In the early Han Dynasty, the ruling class was dominated by military officials. The simplicity of non-interference advocated by Taoism politics was more acceptable than the complex Confucianism. Therefore, in order to restore production, the rulers absorbed the Taoist concepts of ruling by doing nothing and resting with the people. But with the prosperous development of society and economy and the increasing centralization of power, Huanglao thought could not sustain the interests of the emperor and could not adapt to the needs of ruling. Thus after the Han Dynasty, Confucianism became the only official orthodoxy, helping many ancient dynasties to control the minds of their people and achieve a great unification of thought. Because it was Emperor Wu of Han who finally and directly caused Confucianism to become the official guiding ideology, most previous articles and studies on Confucianism in the Han Dynasty have focused on the dispute between Confucianism and Huanglao in the Han 
Dynasty, or on Dong Zhongshu's dismissal of the hundred schools and his exclusive respect for Confucianism, while few have studied the development of Confucianism before Emperor Wu of Han, and few have noticed that Confucianism actually influenced the whole country from the very beginning of the Han Dynasty.

Therefore, how did Confucianism become the officially recognized guiding ideology in less than a century, from the establishment of the Han dynasty to the time of Emperor Wu? How did it quickly integrate and replace most schools of thought and establish a unique position? How did Emperor Wu successfully implement the dominant ideological reform with almost no resistance? This paper will focus on Confucianism under the Han emperor, attempting to address these questions and trying to explore how Confucianism was accepted before the Han emperor and in what ways the Han emperor showed Confucian tendencies. This paper especially focuses on and discusses the development of Confucianism in the period of Emperor Wen of the Han Dynasty.

\section{THE CHANGES OF MAINSTREAM THOUGHT IN THE EARLY HAN DYNASTY}

\subsection{The establishment of prior mainstream ideology: Huang-Lao}

Since Qinshihuang believed in Legalism, he set up a series of harsh laws, and extorted excessive taxes and levies. With building a great bustle of masons and using all armed might to indulge in aggressive wars, the Great Empire of Qin only survived for 15 years and collapsed. With the long period of wars and chaos, the whole society and economics was serious damaged. The whole state was seriously poor. At the beginning period of Han, the whole state had to continue the terrible situation. The adult men all joined the army and the old had to transport the provisions for troop. There was lack of material and the production. The ordinary people almost had nothing [1].

In this circumstance, people all desire a peaceful and stable life. Gaozu, Queen Lv and counsellor Chen Ping, Xiao He and Cao Can were all influenced by "ProtoTaoist" Huang-Lao, so they abolished the Legalism and chose Huang-Lao as the mainstream ideology for the state. Gaozu let soldiers go back home to do the farming and exempted their corvee with retaining the commerce. These measures facilitated the stability of the society and the rehabilitate of the economics which were supported by the people.

During the period of Wen-Jing, there was a trend of the Taoism to the Confucianism. Although the mainstream ideology was still the Huang-Lao, the
Confucianism was widely publicized and some Confucian scholars became officials. All the society became more honest and kind. The criminal without too much evidence was released. In this way, the punishment largely decreased [2]. During the period of Emperor Jing, since Queen Dou implemented Huang-Lao, the government did not adopt Confucian scholars as officials [1][3].

In these 70 years, thanks to the implementation of Huang-Lao, the whole empire became stronger which set up the foundation for Emperor Wen's prosperity.

\subsection{The Confucianism in the early Han Dynasty}

During the period of establishment of Han, a great number of Confucian scholars gave advice and suggestions for him. Although Gaozu was great influenced by Huang-Lao, he still adopted the good advice from them and appointed them [4]. After Han set up, the Confucian scholars began to study the etiquette again. However, the emperor was busy with war and had no time to settle schools. During the period of Emperor Hui and Queen Lv, the officials were all soldiers. As the time came to the period of Emperor Wen, there were only a few Confucian scholars. When the Emperor Jing came to people's view, the Confucianism still was not paid attention to [1].

When the Emperor Wen was attached to the throne, he wanted to find a person who could teach Shangshu. Among those who could reach the expectation, the Confucian scholars were the most. The Confucian scholars such as Lu Jia and Jia Yi gave lecture and taught others who all indulged in the construction and consolidation of the empire. With holding the thought of the Confucianism, they also absorbed other schools' beneficial parts and further developed the Confucianism.

When Lu Jia gave advice to the Emperor, he always cited quote from the Confucian books, Shi and Shu, to highlight that although the Emperor got the state by military force, he should rule the state with benevolence. He wrote a book, Xinyu, which told the reasons of the surviving and collapsing of each dynasty, the crucial point was the benevolence and justice. The book was highly recommended by Gaozu. Lu Jia gave a thought of a blend of delicacy and force which was derived from Huang-Lao. Jia Yi recommended benevolence and justice and took proper rite seriously. During the Emperor Wen, he set up a system of etiquette and wrote Guoqinlun and Zhianshu. He thought Qin refused to be benevolent to people, so that Qin lost advantage eventually. He thought benevolence and justice should both exist. However, benevolence was much more important than justice. The emperor should love their people and the state should make their people happy and wealthy [5]. The proper rite would make people have realization of precedence and be polite to each other. The society was hierarchical, so 
that the status of Emperor could not be violated [2]. Thanks to the effort to those Confucian scholars who made the Confucianism more realistic and could be better adopted by the rulers.

\subsection{The inevitability of venerating Confucianism during the period of Emperor Wu}

At the beginning period of Han Dynasty, Huang-Lao conformed to the requirement of the era and gained people's support. It facilitated the rehabilitation and development of the economics. However, with the long period of "govern by doing nothing that going against nature" also resulted in the social contradictions. Land annexation, corrupt officials, luxurious, the disintegration of the whole society and the disturbance to the border were all the problems faced by the Han. In this way, the ruling of "govern by doing nothing that going against nature" came into the end [6]

At the same time, the Confucian scholar, Dong Zhongshu had already organized and set up a new system of Confucianism. Orienting the thought of Confucianism, the new system absorbed the advantage of Huang-Lao, Legalism and Yin-Yang. Finally, the new system took the heaven-human induction as the foundation and took the Gongyang School as the central thought which fully met the need of the centralization of the empire in the feudal society in ancient China.

The Emperor Wu was a ruler with outstanding ability, who put the Confucianism scholars, such as Tian Fen and Dou Ying, in an important position when he acceded to the throne. He latter adopted the advice from the Prime Minister Zhao Huan that all the recommendation should be Confucian scholars. The Emperor Wu also prepared for offering sacrifices to heaven and changed the calendar. Although there were the opposition from Queen Dou and Zhao Huan, Wang Jian were forced to commit suicide, with the pass away of Emperor Dou, the largest impediment was also removed. In the second year, the Emperor $\mathrm{Wu}$ recruited a series of Confucian scholars, such as Gongsun He.

Eventually, the Emperor Wu accepted the advice "ban from hundred philosophers, venerate Confucianism" from Dong Zhongshu and Gongsun He. He finally finished this historical change. After the 2,000 years, the Confucianism kept being the mainstream ideology in the feudal China.

\section{CONFUCIANISM IN THE PERIOD OF EMPEROR WEN}

Compared with the past, Emperor Wen paid more attention to agricultural production. In the first month, Emperor Wen said, "Agriculture is the root of the state, and a piece of land should be opened up for the emperor to personally cultivate, and I will personally take the lead in cultivating it to provide food for the temple rituals" [1]. According to Confucianism, agriculture was the root of the state. It enabled people to concentrate on farming with small population mobility, which was more conducive to the ruler's management of population, family and economy, and had a stable source of tax. Only when the basic needs of the people were met could we talked about rituals and morality. It was believed that agricultural production activities should follow natural seasons and festivals in order to obtain a full harvest Only when the people's basic necessities of life were met could the country be stable [7][8].

Emperor Wen applied the Confucian value of filial piety and fraternal duty to all aspects of society, which was called "ruling the world with filial piety". And he also set an example by being diligent and loving to the people, focusing on resting with the people and implementing a series of policies and measures to benefit the people and to secure them [1]. He made filial piety and fraternal duty a criterion for admitting officials and strongly praised filial people, setting them up as role models for the whole nation. After his death, even his own name had the word "filial piety" and was awarded Emperor Xiaowen.

Emperor Wen's attitude towards Confucianism has changed, and the rulers' attitude towards Confucianism has also been improved. Not all officials in the early Han period agreed with Confucianism. They believed that Confucianism was not the way to rule the world at the beginning of the dynasty, because it covered a wide range and had little demand. In order to restore production, the rulers absorbed the Taoist concept of noninterference and rest with the people. Also in the early Han Dynasty, the ruling class was dominated by military officials and came from the lower classes. The simplicity of non-interference advocated by Taoist politics was more easily accepted than the complex Confucianism. With the passage of time, in the period of Emperor Wen of the Han Dynasty, Taoism threatened the imperial power, and the government had to rethink its guiding ideology, which was an important step taken in the period of social transformation. Since the policy was ideologically determined, he urgently needed to find a new way to strengthen the power of the emperor and weaken the power of the princes and nobles. There were two theories available to the emperor at that time, namely Confucianism and Legalism. Both of them emphasized the supremacy of the king and the obedience of the monarch's officials. Legalism was too strict and the Qin dynasty was overthrown as a result, so Confucianism became the preferred choice. However, the historical records in shiji have led many people to believe that Emperor Wen of Han also did not value Confucianism like his ancestors, and that "Emperor Wen preferred the teachings of Taoism" [1]. However, some scholars have pointed out that Emperor Wen's preference for penal 
names and Emperor Jing's non-appointment of Confucianists were largely disguised manifestations out of this Taoist preference. The "non-appointment of Confucianists" was only an outward expression of the political pressure of the two emperors at that time, not because they really did not value Confucianism [9]. In fact, Emperor Wen and his successors were very friendly to Confucianism and made efforts for its. They began to systematically collect and organize Confucian texts and to value and recruit Confucian scholars. He selected officials through Confucian classics [2], created special positions for Confucian scholars to ensure their political status, and further improved the political status of Confucian officials [9].

Emperor Wen applied Confucianism to explain natural phenomena, which called doctrine of the induction of heaven and man. It could be interpreted as a kind of idealistic theology, meaning that heaven and man were connected and sensed each other, and that heaven could intervene in human affairs and man could sense heaven. If the Son of Heaven violated the will of Heaven and was unkind and unrighteous, Heaven would condemn and warn him of the calamity. If the government and people were in harmony, Heaven would send down auspicious rites to encourage him. The earliest written record of the doctrine of the induction of heaven and man was the Confucian text Shang Shu, which stated that the weather would change with the performance of the monarch. Here are various good signs: when the monarch performs well, various good weather will follow; rain will fall in time; the weather will clear in time; the climate will be warm in time; cold will come in time. Here are various bad signs: when the king has a fault, there will be long-lasting rain; long-lasting drought without rain; long-lasting heat; long-lasting cold; and long-lasting wind [2]. Confucius believed that the attitude of the ruler's governance could influence the change of weather. It is recorded in shiji that a solar eclipse occurred on the last day of November and another one on December 15. Emperor Wen said, "I have heard that all nations were created by God and that kings were sent to nurture and manage them. If a ruler does not speak virtuously and lead his country justly, God will bring him disaster and warn him of bad governance. This episode describes Emperor Wen's attitude toward natural disasters, which he blames on himself, believing that his cruelty and unkindness led to God's punishment of him and his people, and telling him to reform. [1]" The most important point that we can see from these words is that Emperor Wen has shown a Confucian tendency by mentioning the concept of celestial and human induction, a very important Confucian view after Dong Zhongshu. In short, celestial and meteorological conditions were closely related to the political performance of emperors and rulers. At this time, this concept was not fully developed. The doctrine of celestial induction before Dong Zhongshu was more like a yin and yang doctrine, in which there was an inductive relationship between heaven and man, and human behavior would be reflected to heaven, and heaven would be reflected to man according to the good and evil of human behavior. In his later reforms, Dong Zhongshu made it more systematic and established a whole set of theological worldviews, which politically justified the legitimacy and rationality of autocratic rule, fictionalizing the supremacy of heaven in order to establish the supreme authority of the emperor to maintain and strengthen the rule of earthly monarchs. But even so, this does not mean that we cannot assume that Dong Zhongshu was influenced by Emperor Wen or that Emperor Wen laid the foundation for the later doctrine of celestial induction.

The last point that proves the Confucian tendency of Emperor Wen of Han Dynasty is that Emperor Wen of Han Dynasty chose to rule the country by virtue, teach the world, and set an example for the world with his own virtue. Confucius ever said, "By governing the state with the power of morality, one will be like the North Star, peacefully in its place, with all the other stars surrounding it. [12]" He believed that as a leader, virtue could make his followers follow him voluntarily. Emperor Hanwen urged people around him to be thrifty, reduce funeral expenses, and prohibit burying himself very deeply. "Today's world likes to live, but does not like to die. When people die, they must be buried very deeply, so as to destroy their family property, which I am very unhappy about" [1]. Not only that, he also issued more than one decree to reflect on his mistakes. He promulgated a series of social welfare measures to protect the livelihood of the lower class and reward them with food and wine. These laws were frequently issued and widely welcomed. Finally, he encouraged officials to point out their mistakes. Officials are placed in different positions according to their different political talents and aspirations.

\section{CONCLUSION}

Confucianism has been an influential ideology in China from ancient times to the present. After the Han Dynasty, Confucianism became the only official orthodoxy that helped many ancient dynasties control the minds of their people and achieve a great unification of thought. But it all began when Emperor Wu of the Han Dynasty dismissed the hundred schools of thought and revered only Confucianism. For a number of historical, political, cultural and educational policies as well as its own ideological reasons, Confucianism became orthodox during the Han Dynasty.

This paper mainly combs the changes of mainstream thought in the early Han Dynasty, that is, the development process from paying attention to Hung-Lao to advocating Confucianism. At the same time, it focuses on the basic attitude and main utilization of Confucianism by the rulers in the period of Emperor Wen 
of the Han Dynasty. This paper holds that it is a historical necessity for Confucianism to become the leading thought of national rule in the period of Emperor $\mathrm{Wu}$ of the Han Dynasty, and its basis is the gradual attention and attention to Confucianism in the early Han Dynasty, especially the important contribution of Emperor Wen of the Han Dynasty. The research on the development of Confucianism in this period is not deep enough and will be further supplemented and improved in the future.

\section{REFERENCES}

[1] Sima Qian, Shi Ji, Zhonghua Book Company, 2013.

[2] Ban Gu, Hanshu, Zhonghua Book Company, 2005.

[3] Chen Hui, The development of Confucianism in the early Western Han Dynasty, Journal of Huaibei Coal Normal University, 2006 (02), pp.43-45.

[4] Liu Degui, The difficult course of the development of Confucianism in the early Han Dynasty, Journal of Hunan Business University, 2001 (02), pp.80-81.

[5] Xia Zengmin, The transformation and phased development of Confucianism in the early Western Han Dynasty: centered on Lu Jia and Jia Yi, Qin Han research, 2015 (00), pp.125-133.

[6] Ding Sixin, Debate on "deposing hundreds of schools and respecting Confucianism alone" and refutation of the autocratic theory of Confucian academic thought in the Han Dynasty, Confucius Research, 2019 (03), pp.126-138.

[7] Mencius, Zhonghua Book Company, 2010.

[8] Zhang Xiaofang, A brief discussion on pre Qin Confucian agricultural thought, Agricultural Archaeology, 2015 (03), pp.101-107.

[9] Ge Libin, On the measures of Emperor Wen and Emperor Jing in the early Han Dynasty to worship Confucianism, Jinan Journal, 2012, 34 (05), pp.8592.

[10] Confucius, Analects of Confucius, Zhonghua Book Company, 2006. 